\title{
Distribution and Abundance of Archaea in South China Sea Sponge Holoxea sp. and the Presence of Ammonia-Oxidizing Archaea in Sponge Cells
}

\author{
Fang Liu, ${ }^{1}$ Minqi Han, ${ }^{1}$ Fengli Zhang, ${ }^{1}$ Baohua $\mathrm{Zhang}^{2}$ and Zhiyong $\mathrm{Li}^{1}$ \\ ${ }^{1}$ Marine Biotechnology Laboratory, State Key Laboratory of Microbial Metabolism and School of Life Sciences and Biotechnology, \\ Shanghai Jiao Tong University, 800 Dongchuan Road, Shanghai 200240, China \\ ${ }^{2}$ Eastern Hepatobiliary Surgery Hospital, Second Military Medical University, Changhai Road 225, Shanghai 200438, China
}

Correspondence should be addressed to Baohua Zhang, zhbh_1@tom.com and Zhiyong Li, zyli@sjtu.edu.cn

Received 14 January 2011; Revised 13 May 2011; Accepted 28 June 2011

Copyright $\odot 2011$ Fang Liu et al. This is an open access article distributed under the Creative Commons Attribution License, which permits unrestricted use, distribution, and reproduction in any medium, provided the original work is properly cited.

\begin{abstract}
Compared with bacterial symbionts, little is known about archaea in sponges especially about their spatial distribution and abundance. Understanding the distribution and abundance of ammonia-oxidizing archaea will help greatly in elucidating the potential function of symbionts in nitrogen cycling in sponges. In this study, gene libraries of $16 \mathrm{~S}$ rRNA gene and ammonia monooxygenase subunit A $(a m o A)$ genes and quantitative real-time PCR were used to study the spatial distribution and abundance of archaea in the South China Sea sponge Holoxea sp. As a result, Holoxea sp. specific AOA, mainly group C1a (marine group I: Crenarchaeota) were identified. The presence of ammonia-oxidizing crenarchaea was observed for the first time within sponge cells. This study suggested a close relationship between sponge host and its archaeal symbionts as well as the archaeal potential contribution to sponge host in the ammonia-oxidizing process of nitrification.
\end{abstract}

\section{Introduction}

The biodiversity and biogeography of sponge microbial symbionts has received a great deal of attention, and the past 10 years has witnessed huge advances in revealing the phylogenetic diversity of sponge symbionts. Until the beginning of 2011, 30 bacterial phyla and 2 archaeal phyla have been detected in sponges [1]. However, the role of microbial symbionts remains largely unknown [2-4] and the nature of the sponge-microorganism interaction has to date only been inferred from loose correlations [2]. The present information of sponge microbial symbionts is mainly on the microorganisms in sponge mesohyl, that is, extracellular symbionts [5]. The difficulty in identifying and discriminating between intra- and extracellular symbionts has made it hard to determine the true nature of sponge-microorganism interactions. Therefore, investigation of the intracellular symbionts, which are likely "true" and "stable" symbiotic populations and may play a more significant role in the sponge biology and ecology, is very helpful for the understanding of sponge-microorganism interaction and the roles of sponge microbial symbionts.
Up to now, evidence of intracellular symbionts of sponges is mainly derived from transmission electronic microscopy (TEM) visualization analyses. For example, intracellular algal symbionts in sponges were first confirmed by TEM in 1979 [6]. Using a similar approach, intracellular dinoflagellates [7], filamentous unicellular cyanobacteria [8], and yeast [9] have been observed in sponges. Furthermore, a complex bacterial consortium was revealed in Ectyoplasia ferox oocytes using fluorescent in situ hybridization (FISH) in 2008 [10]. Because TEM- or FISH-based methods can provide only limited phylogenetic information, the diversity and abundance of intracellular endosymbionts in sponge cells remain poorly understood.

Numbers of studies on archaeal sponge symbionts have emerged since 1996 [11-15]. The recent discovery of genes responsible for ammonia oxidation in sponge-associated crenarchaea and evidence of vertical transmission of these symbionts strongly support the argument that these archaea are essential for the metabolism of the sponge host $[16,17]$. Though diverse archaea have been observed in sponges [12$15,18]$, little is known about the spatial distribution and abundance of archaea in the sponge host and we do not know 


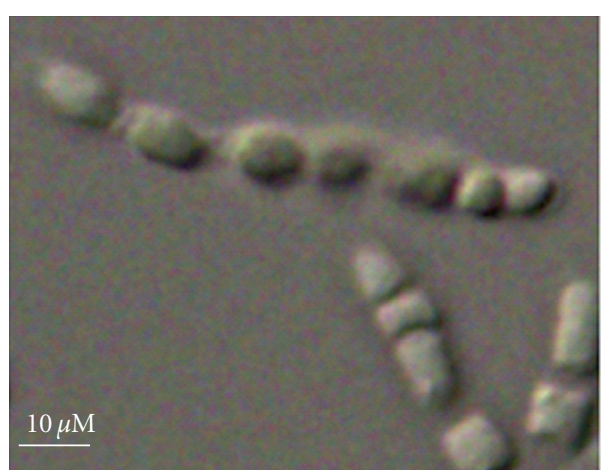

(a)

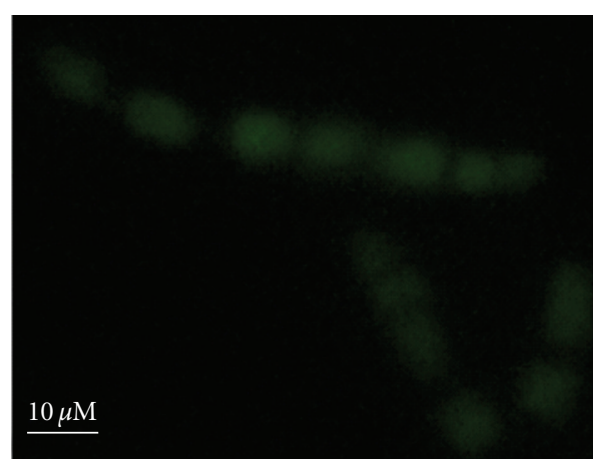

(b)

FIgURE 1: Sponge cells isolated in this study (a) and their autofluorescence (b) $(\lambda=480 \mathrm{~nm})$.

whether there are archaea in sponge cells. Thus, the examination of the spatial distribution, diversity, and abundance of archaea within sponges especially in sponge cells will greatly help in better understanding the role of archaea play in sponge biology and ecology.

In this study, gene library and quantitative real-time quantitative PCR (RT-qPCR) were used to determine the distribution, diversity, and abundance of archaea in the different parts such as cells and mesohyl of South China Sea sponge Holoxea sp. The copy number of ammonia-oxidizing genes was also studied to assess the distribution of the AOA community in different parts of sponge Holoxea sp. It is the first report of intracellular archaeal symbionts in marine sponges.

\section{Materials and Methods}

2.1. Sampling and Cell Sorting. Marine sponge Holoxea sp. was collected nearby Yongxing Island $\left(112^{\circ} 20^{\prime} \mathrm{E}, 16^{\circ} 50^{\prime} \mathrm{N}\right)$ in the South China Sea at depth of $c a .20 \mathrm{~m}$ and processed as described by Li and Liu [19]. Small cubes of sponge tissues $\left(<0.5 \mathrm{~cm}^{3}\right)$ were transferred into a $100 \mathrm{~mL}$ conical flask and washed using $40 \mathrm{~mL}$ sterile artificial seawater (ASW) (1.1 g $\mathrm{CaCl}_{2}, 10.2 \mathrm{~g} \mathrm{MgCl}_{2} 6 \mathrm{H}_{2} \mathrm{O}, 31.6 \mathrm{~g} \mathrm{NaCl}, 0.75 \mathrm{~g} \mathrm{KCl}, 1.0 \mathrm{~g}$ $\mathrm{Na}_{2} \mathrm{SO}_{4}, 2.4 \mathrm{~g}$ Tris- $\mathrm{HCl}$, and $0.02 \mathrm{~g} \mathrm{NaHCO}$, $1 \mathrm{~L}$ distilled water, $\mathrm{pH}$ 8.2) 3 times for $40 \mathrm{~min}$ with shaking at $150 \mathrm{rpm}$ and $20^{\circ} \mathrm{C}$. The resulting artificial seawater, which contained extracellular ectosymbionts, was collected, filtered using 300-mesh stainless steel sieve, and further centrifuged at $15,000 \times \mathrm{g}$ to gain extracellular ectosymbionts which refers to microbes loosely attached to the sponge surface and canals, choanocyte chambers (sample W).

The resulting tissue cubes were disintegrated in $\mathrm{Ca}^{2+}$ and $\mathrm{Mg}^{2+}$-free ASW and were separated using differential centrifugation method described previously [20]. The tissue cubes washed from the previous step were dissociated in $\mathrm{Ca}^{2+}$ - and $\mathrm{Mg}^{2+}$-free ASW at $110 \mathrm{rpm}$ and $20^{\circ} \mathrm{C}$ for $60 \mathrm{~min}$. The resulting cell suspension was filtered using 300-mesh stainless steel sieve. Holoxea sp. has thin outer layer (1-2 mm thick). After $60 \mathrm{~min}$ disassociation, outer layer remained intact and was removed through the filtration. Sponge cells, named sample B for analysis of intracellular archaea, were collected by centrifugation at $300 \times \mathrm{g}$ for $10 \mathrm{~min}$, and the supernatant was transferred into a new tube. The resulting pellets were rinsed three times with $\mathrm{Ca}^{2+}$ - and $\mathrm{Mg}^{2+}$-free ASW and identified to be free of bacteria from mesohyl by their autofluorescence $(\lambda=480 \mathrm{~nm})$ (Figure 1). No bacterialike particulates were found, which proved that the obtained sponge cells were free of bacteria from mesohyl and, thus, were used for diversity analysis of intracellular prokaryotic symbionts of sponge. Supernatants resulted from the previous step were further centrifuged at $15,000 \times \mathrm{g}$ for $10 \mathrm{~min}$. The resulting pellet was named sample J and used to analyze extracellular archaeal endosymbionts (mesohyl).

Sponge tissues without treatments above, named sample $\mathrm{T}$, were used to extract genomic DNA for the analysis of the total communities of bacteria associated with the sponge Holoxea sp.

2.2. DNA Extraction, Gene Library Construction, and RT$q P C R$. Genomic DNA was extracted from samples B, J, and $\mathrm{W}$ and sponge specimens (sample $\mathrm{T}$ ) using the QIAGEN genomic tip protocol. To target the diversity of archaeal community, archaea-specific 16S rRNA gene primer set 21F/ 958R [21] was used for the construction of 16S rRNA gene libraries, named as BArc, JArc, WArc, and TArc for samples $\mathrm{B}, \mathrm{J}, \mathrm{W}, \mathrm{T}$, respectively. The $16 \mathrm{~S}$ rRNA gene was amplified using the Arch21F/Arch958R primers with the following PCR condition: $95^{\circ} \mathrm{C}$ for $3 \mathrm{~min} ; 35$ cycles of $95^{\circ} \mathrm{C}$ for $30 \mathrm{~s}$, $55^{\circ} \mathrm{C}$ for $30 \mathrm{~s}, 72^{\circ} \mathrm{C}$ for $1 \mathrm{~min} ; 72^{\circ} \mathrm{C}$ for $10 \mathrm{~min}$. Ammonia monooxygenases subunit $\mathrm{A}(\mathrm{amo \textrm {A }})$ gene was amplified with primer pair Arch-amoAF/Arch-amoAR [22] from sample T's genomic DNA to construct an amoA gene library. The PCR condition: $95^{\circ} \mathrm{C}$ for $3 \mathrm{~min} ; 35$ cycles of $95^{\circ} \mathrm{C}$ for $30 \mathrm{~s}, 53^{\circ} \mathrm{C}$ for $45 \mathrm{~s}, 72^{\circ} \mathrm{C}$ for $45 \mathrm{~s} ; 72^{\circ} \mathrm{C}$ for $5 \mathrm{~min}$.

The abundance comparison of archaea amoA gene between different samples was made using real-time quantitative PCR (SYBR Premix Ex Taq II, Takara) with primer set amoA19F/amoA643R [23]. As a control, universal archaea $16 \mathrm{~S}$ rRNA gene primer set 340F/519R [24] was used to quantify the total archaea in the four samples. Specificity for realtime PCR reactions was tested by electrophoresis through a $1.5 \%$ agarose gel and melting curve analyses. Copy numbers of amoA and 16S rRNA gene were determined using external standards. A standard curve that describes the relationship 


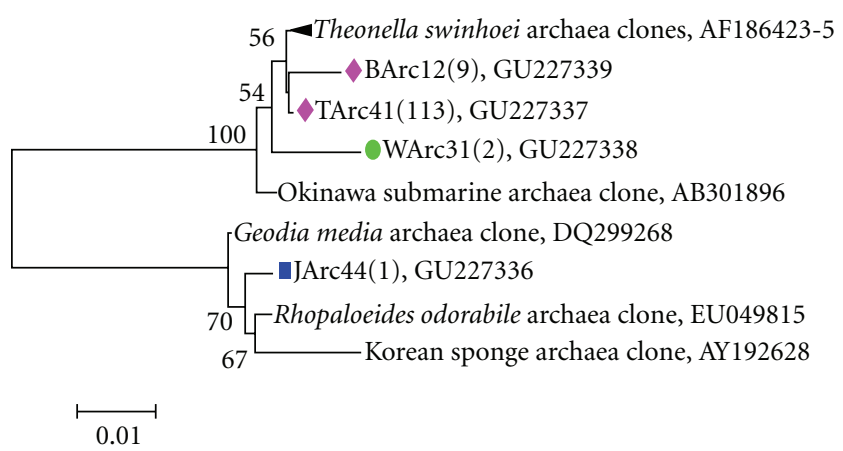

FIGURE 2: Unrooted 16S rRNA gene-based phylogenetic consensus tree displaying the affiliation of sponge-associated Crenarchaeota within group $\mathrm{Cla}$ (marine group I: Crenarchaeota). Bootstrap values under 50\% were cut off after 100 resamplings. Bar: 1 nucleotide substitutions per 100 nucleotides. Numbers in parenthesis stand for the number of clones found in individual library.

between archaeal and bacterial amoA copy numbers and cycle threshold (CT) values was generated using serial dilutions of a known copy number of the 16S rRNA and amoA genes of the plasmid DNA: 16S rRNA, GU227337; amoA, GU216235. We calculated the copy numbers directly from the concentration of extracted plasmid DNA by spectrophotometry (Nanodrop Technologies, Rockland, Del, USA). Melting curve analysis was performed from $55^{\circ} \mathrm{C}$ to $95^{\circ} \mathrm{C}$ with a reading made every $1^{\circ} \mathrm{C}$ and the samples held for $1 \mathrm{~s}$ between readings.

2.3. Statistical and Phylogenetic Analysis. Operational taxonomic units (OTUs) were defined as sequence groups in which sequences differed by $\leq 1 \%$ ( $2 \%$ for amoA). Nonparametric richness estimations were performed using DOTUR [25]. A representative clone of each OTU was selected for further phylogenetic analysis. All the OTUs and their closest neighbors determined by BLAST were imported into MEGA 4 [26] for the construction of neighbor-joining trees. Sequences obtained in this study were deposited in the NCBI Genbank under accession numbers: GU227336-GU227339 (16S rRNA archaea) and GU216235-GU216243 (amoA archaea).

\section{Results and Discussion}

3.1. Distribution and Diversity of Archaeal Symbionts in Holoxea sp. According to this study, the archaea community in Holoxea sp. was rather simple; all the representative clones in the four groups were identified as group C1a (marine group I: Crenarchaeota) and their closest relatives were sponge-derived sequences. Only four OTUs were observed and the biggest one (TArc41) contained 113 clones, including the sequences from all samples. Based on this study, the spatiospecificity for archaea in Holoxea sp. was not significant. JArc44 represented the only one singleton (sequence that only occurs in one sample). In phylogenetic tree (Figure 2), these OTUs were divided into two groups: (1) nonsingleton sequences related to Theonella swinhoei

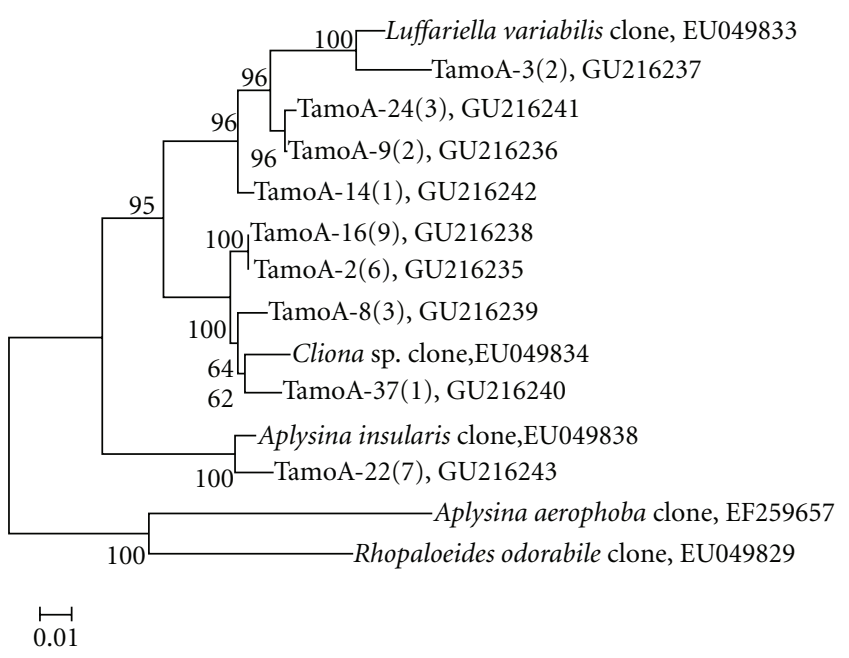

FIGURE 3: Unrooted amoA-based phylogenetic consensus tree of AOA affiliated with the group C1a (marine group I: Crenarchaeota). Bootstrap values under $50 \%$ were cut off after 100 resamplings. Bar: 1 nucleotide substitutions per 100 nucleotides. Numbers in parenthesis stand for the number of clones found in library.

associated archaea and (2) JArc44 located in another spongespecific crenarchaeota clade.

Analysis of amoA gene fragments of sponge sample $\mathrm{T}$ revealed a relative high diversity of ammonia-oxidizing archaea (AOA) in sponge Holoxea sp. Richness analysis (observed phylotypes/predicted $\mathrm{S}_{\mathrm{ACE}}=0.8974$ and observed phylotypes/predicted $S_{\text {Chaol }}=0.9827$ ) indicated that the amoA gene library was large enough to yield a stable estimate of phylotype richness. According to the phylogenetic tree in Figure 3, three branches of Holoxea sp. associated AOA community including 9 OTUs could be identified based on $2 \%$ cutoff. All the amoA genes detected were affiliated with the marine group C1a clones $[16,27]$ and the diversity was noticeable: three branches, respectively, related to Luffariella variabilis, Cliona sp., and Aplysina insularis were identified, which highlighted the ubiquitous distribution of AOA in marine sponges. Almost all the amoA genes clustered together suggesting Holoxea sp. specific AOA. Comparing to the Figures 2 and 3, the phylogenetic affiliation was not coherent, possibly suggesting that horizontal gene transfer has occurred.

3.2. Abundance of AOA Varied in Different Parts of Sponge Holoxea sp. RT-qPCR displayed an interesting picture, as the proportion of AOA in archaea community indicated in Table 1, the proportion of AOA in intracellular archaeal community (sample J and sample B) was greater than that in extracellular archaeal community (sample $\mathrm{W}$ ); especially the proportion of intracellular AOA (sample B, 11.67\%) was nearly 3 -fold that of AOA in sponge mesohyl (sample J, $4.24 \%$ ), which strongly suggested the presence of AOA within sponge cells. Sponge cells would not uptake microbes randomly [28]. The mechanisms of the presence and transfer of $\mathrm{AOA}$ in Holoxea sp. are unknown. It has been shown 
TABLE 1: Abundance of archaea and AOA in different parts of sponge Holoxea sp.

\begin{tabular}{|c|c|c|c|}
\hline \multirow[t]{2}{*}{ Sample } & \multicolumn{2}{|c|}{ Copy number ${ }^{\mathrm{a}}$} & \multirow{2}{*}{$\begin{array}{c}\text { Average } \\
\text { proportion of } \mathrm{AOA}\end{array}$} \\
\hline & amoA (AOA) & $\begin{array}{c}\text { archaea } 16 S \\
\text { rRNA }\end{array}$ & \\
\hline $\mathrm{T}$ & $1.71 \pm 0.33 \times 10^{3}$ & $3.36 \pm 0.48 \times 10^{4}$ & $5.10 \%$ \\
\hline $\mathrm{W}$ & $1.00 \pm 0.24 \times 10^{3}$ & $4.35 \pm 0.55 \times 10^{4}$ & $2.30 \%$ \\
\hline $\mathrm{J}$ & $2.33 \pm 0.09 \times 10^{3}$ & $5.50 \pm 0.31 \times 10^{4}$ & $4.24 \%$ \\
\hline B & $1.89 \pm 0.21 \times 10^{3}$ & $1.62 \pm 0.29 \times 10^{4}$ & $11.67 \%$ \\
\hline
\end{tabular}

${ }^{a}$ Average copy numbers of target gene in one nanogram total genomic DNA. T: whole sponge tissue sample; W: sample of microbes loosely attached to the sponge surface and canals, choanocyte chambers; J: sample of microbes in the sponge mesohyl; B: the intracellular microbes sample.

that the microbial community in sponges could be established by vertical transmission [10]. Similarly, sponges may be able to capture AOA by vertical transmission [16]. Archaea of group Cla probably play an important role in the ammonia detoxification within marine sponges $[1,16]$. It is known that ammonia oxidation catalyzed by ammonia monooxygenase is the first and rate-limiting step of chemoautotrophic nitrification, the overall oxidation of ammonia to nitrate. Within the sponge body, the AOA would be directly exposed to ammonia released by sponge, so it was suggested that AOA in sponge cells and mesohyl should play a role in ammonia oxidization within the sponge host to remove the toxic ammonia.

It was the first time to find Holoxea sp. specific AOA, mainly group $\mathrm{Cla}$ (marine group I: Crenarchaeota), especially intracellular ammonia-oxidizing archaea in sponge cells. Although the detailed function of the plentiful rest archaea in sponge Holoxea sp. needs to be investigated, the finding of AOA accumulation in sponge cells in this study indicates the potential role of sponge symbiotic archaea, especially the intracellular AOA in ammonia oxidization, and suggests a close relationship between sponge host and its archaeal symbionts. To further advance our understanding of the diversity and function of intracellular endosymbionts in sponges, metagenomics technology and novel culture methods will be productive approaches.

\section{Acknowledgments}

Financial supports from the National Natural Science Foundation of China (NSFC) (41076077, 30821005) and the High-Tech Research and Development Program of China (2011AA09070203) are greatly acknowledged.

\section{References}

[1] O. O. Lee, Y. Wang, J. Yang, F. F. Lafi, A. Al-Suwailem, and P. Y. Qian, "Pyrosequencing reveals high diverse and speciesspecific microbial communities in sponges from the Red Sea," International Society for Microbial Ecology Journal, vol. 5, pp. 650-664, 2010.
[2] N. S. Webster and L. L. Blackall, "What do we really know about sponge-microbial symbioses," International Society for Microbial Ecology Journal, vol. 3, no. 1, pp. 1-3, 2009.

[3] M. W. Taylor, R. T. Hill, J. Piel, R. W. Thacker, and U. Hentschel, "Soaking it up: the complex lives of marine sponges and their microbial associates," International Society for Microbial Ecology Journal, vol. 1, no. 3, pp. 187-190, 2007.

[4] G. Vogel, "The inner lives of sponges," Science, vol. 320, no. 5879, pp. 1028-1030, 2008.

[5] M. W. Taylor, R. Radax, D. Steger, and M. Wagner, "Spongeassociated microorganisms: evolution, ecology, and biotechnological potential," Microbiology and Molecular Biology Reviews, vol. 71, no. 2, pp. 295-347, 2007.

[6] C. E. Williamson, "An ultrastructural investigation of algal symbiosis in white and green Spongilla lacustris (L.) (Porifera: Spongillidae)," Transactions of the American Microscopical Society, vol. 98, pp. 59-77, 1979.

[7] M. J. Garson, A. E. Flowers, R. I. Webb, R. D. Charan, and E. J. McCaffrey, "A sponge/dinoflagellate association in the haplosclerid sponge Haliclona sp.: cellular origin of cytotoxic alkaloids by percoll density gradient fractionation," Cell and Tissue Research, vol. 293, no. 2, pp. 365-373, 1998.

[8] A. E. Flowers, M. J. Garson, R. I. Webb, E. J. Dumdei, and R. D. Charan, "Cellular origin of chlorinated diketopiperazines in the dictyoceratid sponge Dysidea herbacea (Keller)," Cell and Tissue Research, vol. 292, no. 3, pp. 597-607, 1998.

[9] M. Maldonado, N. Cortadellas, M. I. Trillas, and K. Rützler, "Endosymbiotic yeast maternally transmitted in a marine sponge," Biological Bulletin, vol. 209, no. 2, pp. 94-106, 2005.

[10] S. Schmitt, H. Angermeier, R. Schiller, N. Lindquist, and U. Hentschel, "Molecular microbial diversity survey of sponge reproductive stages and mechanistic insights into vertical transmission of microbial symbionts," Applied and Environmental Microbiology, vol. 74, no. 24, pp. 7694-7708, 2008.

[11] C. M. Preston, K. Y. Wu, T. F. Molinski, and E. F. Delong, "A psychrophilic crenarchaeon inhabits a marine sponge: Cenarchaeum symbiosum gen. nov., sp. nov," Proceedings of the $\mathrm{Na}$ tional Academy of Sciences of the United States of America, vol. 93, no. 13, pp. 6241-6246, 1996.

[12] B. Holmes and H. Blanch, "Genus-specific associations of marine sponges with group I crenarchaeotes," Marine Biology, vol. 150, no. 5, pp. 759-772, 2007.

[13] N. S. Webster, J. E. M. Watts, and R. T. Hill, "Detection and phylogenetic analysis of novel crenarchaeote and euryachaeote $16 \mathrm{~S}$ ribosomal RNA gene sequences from a Great Barrier Reef sponge," Marine Biotechnology, vol. 3, no. 6, pp. 600-608, 2001.

[14] H. Margot, C. Acebal, E. Toril, R. Amils, and J. L. Fernandez Puentes, "Consistent association of crenarchaeal archaea with sponges of the genus Axinella," Marine Biology, vol. 140, no. 4, pp. 739-745, 2002.

[15] T. Pape, F. Hoffmann, N. V. Quéric, K. Von Juterzenka, J. Reitner, and W. Michaelis, "Dense populations of archaea associated with the demosponge Tentorium semisuberites Schmidt, 1870 from Arctic deep-waters," Polar Biology, vol. 29, no. 8, pp. 662-667, 2006.

[16] D. Steger, P. Ettinger-Epstein, S. Whalan et al., "Diversity and mode of transmission of ammonia-oxidizing archaea in marine sponges," Environmental Microbiology, vol. 10, no. 4, pp. 1087-1094, 2008.

[17] S. J. Hallam, K. T. Konstantinidis, N. Putnam et al., "Genomic analysis of the uncultivated marine crenarchaeote Cenarchaeum symbiosum," Proceedings of the National Academy of 
Sciences of the United States of America, vol. 103, no. 48, pp. 18296-18301, 2006.

[18] A. S. Turque, D. Batista, C. B. Silveira et al., "Environmental shaping of sponge associated archaeal communities," PloS One, vol. 5, Article ID e15774, 2010.

[19] Z. Y. Li and Y. Liu, "Marine sponge Craniella austrialiensisassociated bacterial diversity revelation based on $16 \mathrm{~S}$ rDNA library and biologically active Actinomycetes screening, phylogenetic analysis," Letters in Applied Microbiology, vol. 43, no. 4, pp. 410-416, 2006.

[20] S. De Rosa, S. De Caro, G. Tommonaro, K. Slantchev, K. Stefanov, and S. Popov, "Development in a primary cell culture of the marine sponge Ircinia muscarum and analysis of the polar compounds," Marine Biotechnology, vol. 3, no. 3, pp. 281-286, 2001.

[21] E. F. DeLong, "Archaea in coastal marine environments," Proceedings of the National Academy of Sciences of the United States of America, vol. 89, no. 12, pp. 5685-5689, 1992.

[22] C. A. Francis, K. J. Roberts, J. M. Beman, A. E. Santoro, and B. B. Oakley, "Ubiquity and diversity of ammonia-oxidizing archaea in water columns and sediments of the ocean," Proceedings of the National Academy of Sciences of the United States of America, vol. 102, no. 41, pp. 14683-14688, 2005.

[23] A. Nakaya, Y. Onodera, T. Nakagawa et al., "Analysis of ammonia monooxygenase and archaeal 16S rRNA gene fragments in nitrifing acid-sulfate soil micocosms," Microbes and Environments, vol. 24, no. 2, pp. 168-174, 2009.

[24] L. Ovreas, L. Forney, F. L. Daae, and V. Torsvik, "Distribution of bacterioplankton in meromictic Lake Saelenvannet, as determined by denaturing gradient gel electrophoresis of PCR-amplified gene fragments coding for 16S rRNA," Applied and Environmental Microbiology, vol. 63, no. 9, pp. 3367-3373, 1997.

[25] P. D. Schloss and J. Handelsman, "Introducing DOTUR, a computer program for defining operational taxonomic units and estimating species richness," Applied and Environmental Microbiology, vol. 71, no. 3, pp. 1501-1506, 2005.

[26] K. Tamura, J. Dudley, M. Nei, and S. Kumar, "MEGA4: molecular evolutionary genetics analysis (MEGA) software version 4.0," Molecular Biology and Evolution, vol. 24, no. 8, pp. 1596-1599, 2007.

[27] K. Bayer, S. Schmitt, and U. Hentschel, "Physiology, phylogeny and in situ evidence for bacterial and archaeal nitrifiers in the marine sponge Aplysina aerophoba," Environmental Microbiology, vol. 10, no. 11, pp. 2942-2955, 2008.

[28] M. Wehrl, M. Steinert, and U. Hentschel, "Bacterial uptake by the marine sponge Aplysina aerophoba," Microbial Ecology, vol. 53, no. 2, pp. 355-365, 2007. 


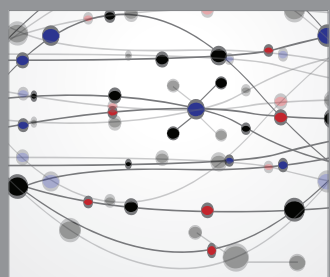

The Scientific World Journal
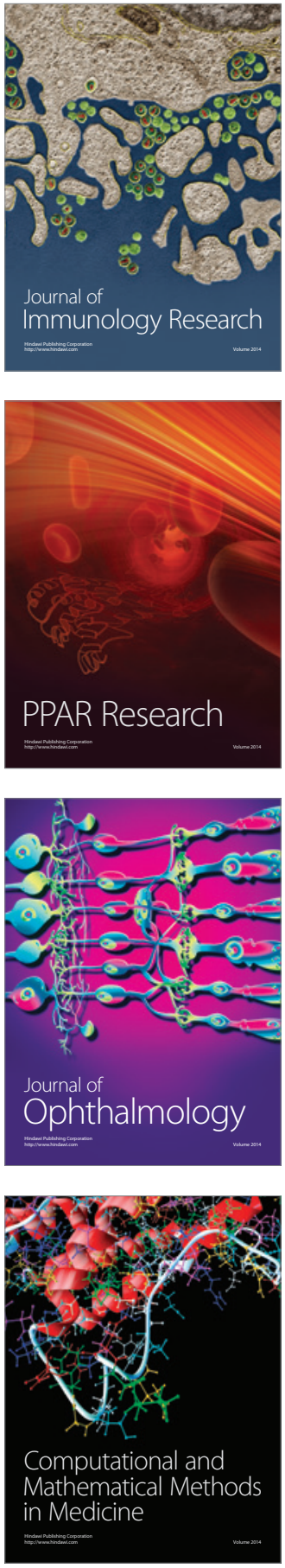

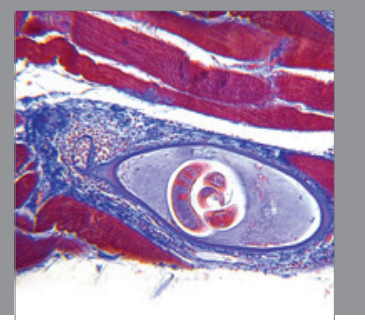

Gastroenterology

Research and Practice
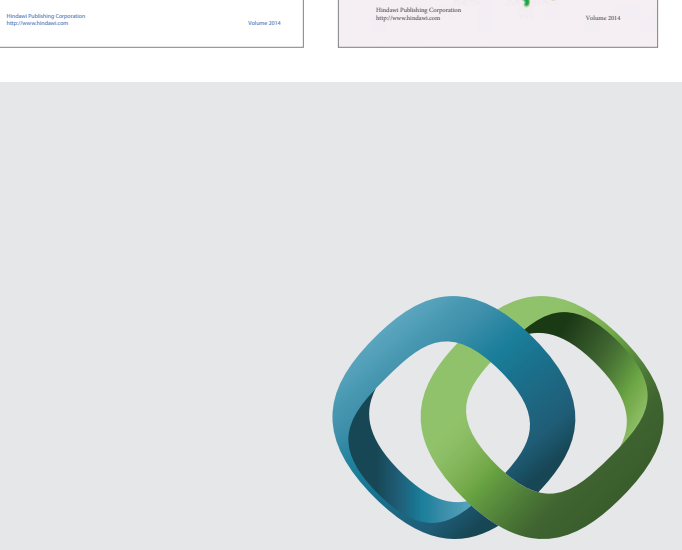

\section{Hindawi}

Submit your manuscripts at

http://www.hindawi.com
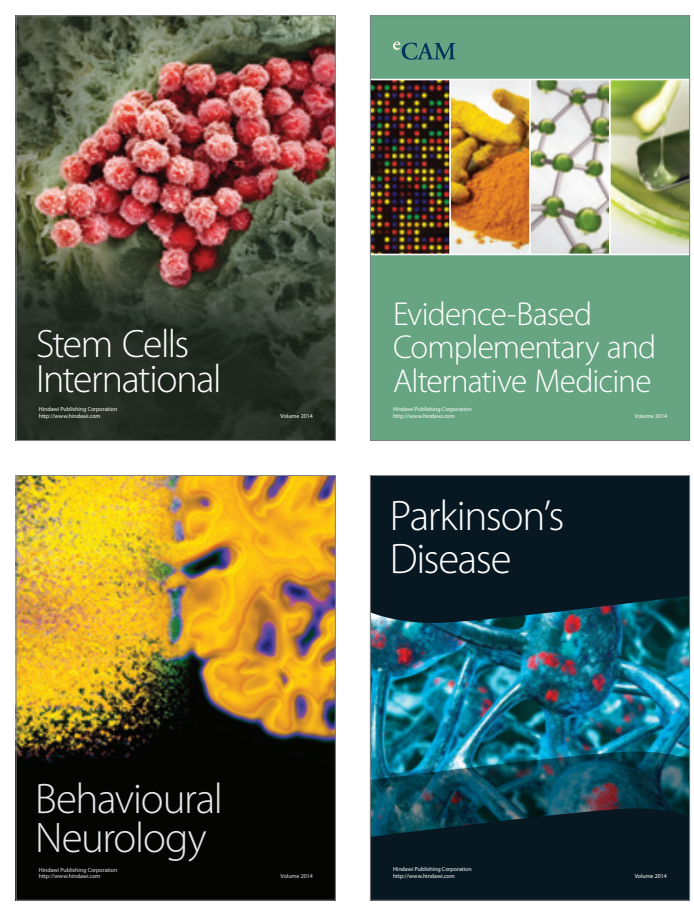

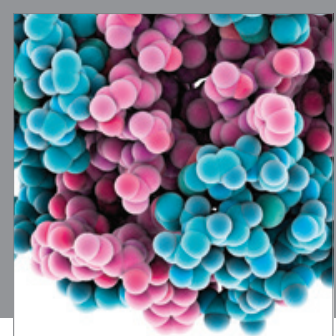

Journal of
Diabetes Research

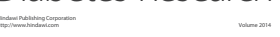

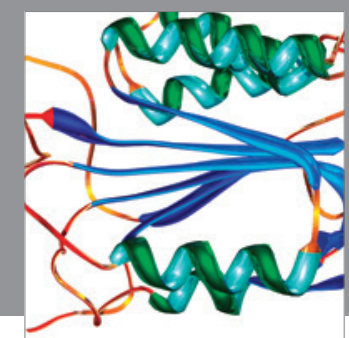

Disease Markers
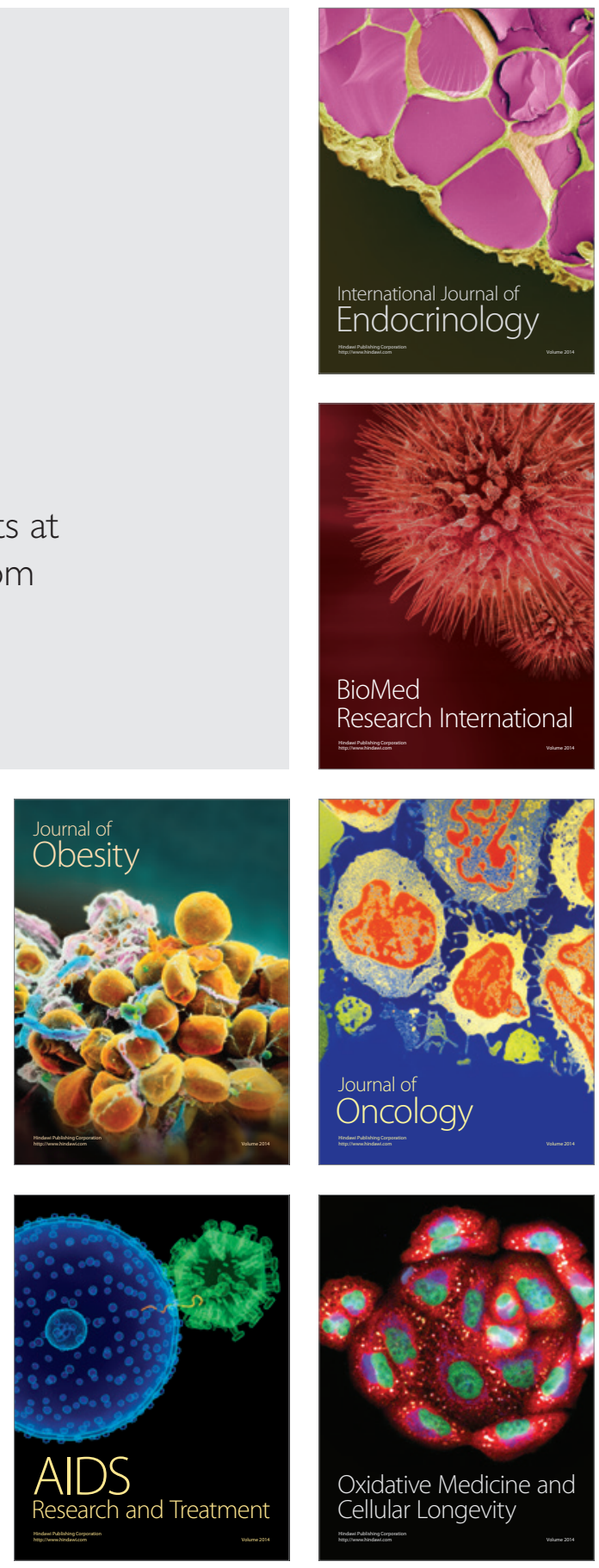